\title{
AS AVENTURAS DO CONHECER: DA TRANSMISSÃO À INTERLOCUÇÃO
}

\author{
Maria Aparecida Affonso Moysés" \\ JoÃo WaNDERLEY GeRALDI* \\ Cecília Azevedo Lima Collares
}

\begin{abstract}
A sólida resistência do nosso corpo e do nosso espírito à reprodução artificial perfeita e à compreensão total oferece, para lá dos limites do conhecimento científico, um vasto campo ao imaginário e à fruição que nunca poderá ser completamente matematizado nem dissecado e no qual repousa, afinal, o prazer de viver.

Paul Caro, $A$ roda das ciências
\end{abstract}

RESUMO: Neste ensaio, utilizando narrativas, os autores analisam as concepções hegemônicas acerca dos modos de produção, circulação e apropriação dos conhecimentos. Esses modos são caracterizados pela despreocupação com os usos e conseqüências dos conhecimentos. $\mathrm{O}$ esgotamento dessas concepções é desvelado pela atual crise de paradigmas e desencadeia novas possibilidades para o mundo científico, pelo reencontro com a vida. Os autores assumem que o sujeito se constitui pela linguagem e pelo processo de constituir seus próprios conhecimentos e propõem a substituição da idéia de conhecimento como objeto transmissível pela de conhecimentos e saberes constituídos nos e pelos processos discursivos. Os autores aventam a importância da memória, das narrativas e da interlocução para o processo em que sujeitos e conhecimentos são simultaneamente tecidos.

Palavras-chave: Sujeito. Conhecimento. Crise paradigmática. Narrativa. Tempo.

* Professora Associada em Pediatria Social da Faculdade de Ciências Médicas da Unicamp. Email: cida.moyses@directnet.com.br

** Professor Associado em Análise do Discurso do Instituto de Estudos da Linguagem da Unicamp. E-mail: geraldi@unicamp.br

*** Professora Associada em Psicologia Educacional da Faculdade de Educação da Unicamp (aposentada).E-mail: cecília.collares@directnet.com.br 


\section{The adventures of KNOWLedge: From transmission to dialogue}

ABSTRACT: Examining narratives, the authors analyze the hegemonic conceptions about the modes of production, circulation and appropriation of knowledge. These modes are characterized by a certain nonchalance as for the use and consequences of knowledge. The exhaustion of these concepts is revealed by the present paradigmatic crisis, which will ultimately propose new modes of knowledge production in the scientific world. The authors assume a subject is constituted by language and knowledge itself. The concept of knowledge as a transmittable thing is thus replaced by the view that knowledge constitutes through discursive processes. The authors propose the importance of memory, narratives and interlocution in these processes where subject and knowledge are closely intertwined.

Key words: Subject. Knowledge. Paradigmatic crisis. Narrative. Time.

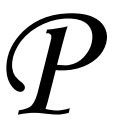

elos céus da cidade, vôo leve e livre, sem amarras: apenas conhecer. É que para isto não se pode ter âncoras. Aprender a olhar o que encontro para extrair lições como aquelas que ensinou Saramago: "Se podes olhar, vê. Se podes ver, repara". Aprendendo a olhar, vou aprendendo que este é o desafio do conhecimento: a dor de assumir que tudo que sei, que conheço, pode ser desmontado, remontado, substituído, estabilizado e até mesmo loucamente fixado por uns tempos.

Também a divagação é parte do conhecer, suspensa quando... Ops! Esperem! $\mathrm{O}$ que é aquilo, o que está acontecendo naquele apartamento? Um rápido mergulho e eis que me defronto com Betina, deitada de costas no chão, com as pernas para o alto, cruzadas em cima do sofá, com toda a atenção em um livro. Um pouco mais de foco e conseguirei ver o nome do livro... Ah! É mais um romance da coleção Sabrina, semelhante em tudo com tantas outras Biancas, Júlias, encanto das moças daqui e de toda parte, objeto de desprezo tanto enunciado por intelectuais de cá e lá.

Foco mais atento: Betina ainda pequena, muito: apenas uma menina de seis anos e lendo já um livro?

A porta se abre, entra uma senhora carregada de bolsa, pasta, pacotes e mais um monte de coisas, como só mesmo uma mulher consegue equilibrar. Certamente estas coisas mesmas nas mãos de um homem, que desastre! Como vocês vêem, realmente aprendi a aprender com o que meu olhar tem alcançado nestes séculos... Cá estou divagando novamente, incorrigível na vontade de aprender com o olhar, mesmo com os riscos de cair sob as vistas de um especialista que me diagnostique uma dessas doenças quaisquer, de nomes difíceis, que com grego arcaico tão facilmente se inventam.

Atenção, elas conversam...

- Betina, o que você está fazendo? Já fez sua lição? Ah! Você está lendo este livro! E está entendendo? 
- Mãe, não entendi o que que é “a-pe-tite se-qui-sual”.

Lá está a mãe, moderna e tão atrapalhada. Rapidamente muda de assunto e ralha, perguntando e ignorando perguntas:

- Já fez sua lição da escola?

- Fiz um pouco, falta uma parte...

- Então vá já fazer!

Betina pega seu material e começa a escrever. Pára e dirige-se à mãe:

- Mãe, me ajuda com uma palavra da família do efe?

- Ferradura.

- Ferradura não pode, porque tem dois erres...

- Mas você sabe escrever ferradura, não sabe? Então por que não pode?

- Porque a tia ainda não ensinou a família dos dois erres, então não posso escrever.

- Mas você já não sabe?

- Eu sei, mas a tia Miriam não pode saber que eu sei, senão ela vai ficar triste... Ops, instabilidade no plano de vôo!!! Emergência em todos os sentidos para captar os sentidos... Arremeter rumo aos céus infinitos.

Aqui no alto, arremetido e já planando, fervilho remoendo sentidos possíveis de um susto grande demais. O que é que estão ensinando pra Betina na escola? Quais mensagens tem a escola sobre esta louca e maravilhosa aventura venturosa que é conhecer? Será aventura que só pode se dar se um outro der a licença? Conhecer virou objeto de práticas cartoriais: sem o registro do que foi dado, o que houve do que (ou)vimos não pode ter havido?

\section{Encruzilhadas de outros tempos e espaços}

A universidade constitui, reconhecidamente, espaço privilegiado de produção de conhecimentos, sendo também privilegiadamente o espaço onde se aprendem conhecimentos. Espaço onde se produz, onde se aprende e, em aparente paradoxo, onde se apreende e também, até mesmo, onde se prendem conhecimentos. Apreender, aprender, prender, vender.

A concepção ainda dominante nas universidades enxerga o conhecimento como um objeto a ser desvelado, externo ao sujeito que busca conhecer e, portanto, dele independente. O conhecimento é concebido como um objeto que circula entre as pessoas, autonomamente, e que pode ser transmitido de um a outro, permanecendo inalterado, não importa em que mãos e mentes repouse. Conhecimentos primeiro, mercadorias amanhã. Embora esta concepção não seja explicitamente discutida com os alunos, ela permeia a maioria dos cursos de formação 
universitária e, assim naturalizada, invade e instaura-se nas mentes dos futuros profissionais, inclusive de possíveis futuros professores universitários. E nestes se enraíza mais fortemente do que os conhecimentos que os formaram. Porque a concepção lhes dá a forma de serem professores: pesquisadores e produtores de novos conhecimentos, alteram e renovam o estoque do sabido sempre da mesma forma transmitido

O fato de não se discutir com os alunos o ato de conhecer e o conhecimento em si reflete um ponto fundamental: no lugar onde se produzem e se aprendem conhecimentos, pouco se reflete sobre o próprio conhecimento, seu significado, seus usos, suas conseqüências. Pouco se reflete sobre o ato de conhecer, sobre o ato de produzir conhecimentos e sobre o sujeito que os produz. Existem, é claro, espaços onde se privilegia a reflexão sobre esta atividade humana, porém tendem a ser pouco valorizados na maioria das áreas em torno das quais se organizam as universidades e pelas quais se disciplina, pela partição, o próprio conhecimento.

Fragilizados ante as pressões externas e internas por uma noção de produtividade imediatista, que poderíamos chamar de "produtos", os profissionais que valorizam e se dedicam a essas reflexões são, muitas vezes, (des)qualificados como aqueles que filosofam.

Duplo paradoxo, nada aparente. Primeiro, porque nos discursos de transmissão, proferidos privilegiadamente diante de sujeitos em tempos de formação, nos espaços reservados e protegidos da cátedra, o conhecimento é um objeto pronto e acabado. Nos discursos teóricos e nas práticas vigentes da pesquisa, no entanto, o conhecimento é um objetivo a ser alcançado, porque um objeto inacabado e flutuante. Segundo, porque, assim concebido, o conhecimento está em constante mutação, as ações desvelando que se está em permanente busca, mas que se quer definitiva: cada qual em sua pesquisa sonhando dizer, enfim, a verdade.

No território das práticas escolares, ao aluno é reservado o papel de um recipiente a ser preenchido pelos conhecimentos transmitidos. Suas capacidades são aí duplamente desenvolvidas; de um lado, como capacidade de armazenamento de objetos com que se o preenche, até seu limite. De outro lado, ele é mensurado/avaliado pela capacidade de aplicação que ele faz/fará desses objetos que lhe vão sendo passados. A esse aluno, receptor duplo, pois passivo e ativo, só resta convencer-se de que tudo que lhe é dado a ouvir ou a ler é verdade. Ou não se convencer. $\mathrm{E}$ os que não se convencem, rapidamente apreendem que é conveniente 
se representar convencidos. O que importa, fundamentalmente, é não pôr sob suspeição os modos de produção e circulação das verdades, mesmo que estas possam ser modificadas.

Preenchido, pronto e acabado, pode o agora egresso retornar ao mundo do mercado, para dar continuidade ao ciclo das circulações de conhecimentos e saberes, tornados mercadorias. Basta que aprenda a vendê-los.

Devo acrescentar que o mercado e a democracia não permitem, por si mesmos, dar uma idéia automática do sentido. O sentido não é um dado ex-ante mas sim uma resultante ex-post. A função da filosofia é portanto a de alimentar o debate que permite escolher e dar um sentido à ação. E lutar também contra um pensamento único, tecnocrático, que se imporia como evidência. (Raux, 1996, p. 17)

São os modos de circulação que autorizam a passagem do sujeito ignorante ao sujeito que sabe. Modos submetidos à regulação e ao controle sociais (Foucault, 1996a) disciplinam sujeitos que somente podem dizer que sabem depois de autorizados por organizações, ritos e rituais previamente estatuídos.

Sem a licença do tempo, Betina não saberá o que é apetite sexual.

Sem a autorização de quem de direito, não escreverá ferradura.

Não importa saber, importa estar autorizado a saber.

É inegável que, ao longo da história, este modo de produção e circulação enriqueceu a experiência humana e construiu possibilidades de melhorias da qualidade de vida, mas também é inegável que os processos de apropriação qualificaram a vida de apenas alguns, permanecendo a maioria da humanidade à margem dos sucessos. Da mesa do banquete fartamente noticiado, migalhas e farelos caíram no prato dos excluídos, minorando seus males e outorgando-lhes a ilusão de partícipes do banquete.

Empanturrados com os excessos, os convivas reais esqueceram até mesmo da continuidade de suas próprias vidas. $\mathrm{O}$ uso inconseqüente de seu semelhante e da natureza, como se fossem recursos infinitos e infinitamente renováveis por auto-regulagem (Morin, 1996a), desnudou as formas de apropriação e os modos de produção e circulação de bens.

Satisfeita com seus modos de produção e de circulação, a ciência moderna esteve sempre insatisfeita com seus produtos, porque surge 
na história sob a ambição de desencantar a realidade, dizendo-a e desenhando-a em seus mapas.

Do rigor da ciência

(...) Naquele Império, a Arte da Cartografia alcançou tal Perfeição que o mapa de uma única Província ocupava toda uma Cidade, e o mapa do Império, toda uma Província. Com o tempo, esses Mapas Desmesurados não foram satisfatórios e os Colégios de Cartógrafos levantaram um Mapa do Império, que tinha o tamanho do Império e coincidia pontualmente com ele. Menos Afeitas ao Estudo da Cartografia, as Gerações Seguintes entenderam que esse dilatado Mapa era Inútil e não sem Impiedade o entregaram às Inclemências do Sol e dos Invernos. Nos desertos do Oeste perduram despedaçadas Ruínas do Mapa, habitadas por Animais e por Mendigos; em todo o País não há outra relíquia das Disciplinas Geográficas. (Suárez Miranda: Viaje de Varones Prudentes, livro quarto, cap. XLV, Lérida, 1658). (Borges, 1999, p. 247)

Vivemos uma época rica em numerosas mudanças que marcam o fim de um período. Este fim se desdobra em três componentes essenciais: a das certezas, a das ilusões e a dos determinismos.

(...)

O homem redescobre hoje que o futuro não é previsível, nem está escrito, mas é profundamente incerto.

A incerteza não se refere unicamente ao que se passa depois da morte mas sobre o período da própria vida. Atinge tanto os indivíduos como as cidades e as organizações. Para termos consciência dela basta recordar o aparecimento do vírus da Sida (Aids), o colapso do império soviético, as catástrofes nucleares de Three Miles Island e de Chernobyl, o tremor de terra de Kobe ou as numerosas desaparições de empresas importantes.

(...)

O fim das ilusões assinala o fato de que História, progresso e moral não caminham forçosamente a par.

O século que finda terá sido talvez um dos piores em termos de barbárie.

(...)

A lição que é preciso tirar é clara: a História não tem moral e o progresso material e econômico de alguns não garante o desenvolvimento de outros. O progresso não tem sentido. A responsabilidade moral do homem não é dada por um sistema mas pelo próprio homem. O sentido, tão reclamado neste final do século 20, não é um dado exterior ao homem mas uma escolha e uma construção do homem, feita no quotidiano, em cada dimensão da sua vida.

(...)

Tudo isto acompanha o fim dos determinismos e daquilo a que se chamou cientismo, a pretensão de querer explicar o homem e o seu futuro por leis que o ultrapassam. (Raux, 1996, p. 11-12) 
Desfeitas as ilusões e promessas da ciência moderna, o novo século se inicia sob o signo de uma urgência: alterar as formas de vida para salvar a vida.

Em vez da eternidade, a história; em vez do determinismo, a imprevisibilidade; em vez do mecanicismo, a interpenetração, a espontaneidade e a auto-organização; em vez da reversibilidade, a irreversibilidade e a evolução; em vez da ordem, a desordem; em vez da necessidade, a criatividade e o acidente. (Santos, 1987, p. 28)

\section{Pesquisar e agir: dos textos às ações}

Os indivíduos, tal como as coisas, percorrem trajectórias situadas no espaçotempo a quatro dimensões. Mas, pelo facto de os seres humanos possuírem uma intencionalidade, uma memória e uma consciência, são capazes de escolher configurações que surgem num dado ponto desta trajectória e, baseando-se nas suas histórias pessoais, submeter estas configurações a planos situados noutros pontos da trajectória. A consciência autoriza deslizes temporais no momento da planificação e isso altera o curso dos acontecimentos. (Edelman, Biologie de la conscience, citado por Raux, 1996)

Talvez deva buscar outras perguntas em outros cruzamentos de tempo e espaço... Atenção, focalizar ali! Isto mesmo, na mosca!

Lá está Miriam, a professora de Betina, conversando com outra professora, a caminho de mais um curso.

- Ih, Rosa, estou tão cansada desses cursos, acho que esse também não vai adiantar muito. Tinha pedido um curso sobre redação de textos e estou fazendo um sobre Piaget... Como sempre, né? Eu não queria estudar agora Piaget, queria saber como fazer para que as crianças aprendam a escrever, gostem de ler e de escrever, acho isso superimportante.

- Eu dessa vez dei sorte, consegui um curso próximo do que eu pedi. No ano retrasado foi um horror, me inscrevi no pedido de ensino de ciências e caí no de alfabetização. E olhe que naquela época eu estava dando aula pra quarta série. - É, neste esquema da Secretaria com a Universidade não dá mesmo muito certo. Eles dizem que consultam, mas dão o que querem. A gente precisa de uma coisa, pede, e recebe outra, geralmente com um professor que nunca deu aula pra crianças, não tem experiência e acha que a gente também não tem. Quando a gente fala das dúvidas em sala de aula, a resposta é sempre a mesma: "Não estou aqui pra dar receita". Como se a gente estivesse pedindo receita...

- Mas também melhorou muita coisa, né Miriam, pelo menos agora ninguém mais diz que vamos pra uma reciclagem! Eu me sentia a própria sucata e sempre tinha medo, só tinha certeza de que entrava Rosa, mas não sabia como ia sair, porque reciclagem é assim, não é? Entra latinha de cerveja e sai placa de alumínio, prontinha pra ser usada de novo. 
- Ai, Rosa, adoro seu humor. É isto que nos salva, o bom humor. E isto eles não conseguiram ainda tirar. Nem reciclar.

Delícia estas gargalhadas, lava a alma e me faz acreditar que o futuro pode ser diferente. Desarma. Puxa vida! Reciclagem também é demais, vocês não acham? Ah, mas lá na pasta delas está escrito "Curso de Capacitação de Professores da Escola Pública”, com um desenho bem grande embaixo, o símbolo, propaganda, garanto.

Melhorou, mas nem tanto. Mudou de reciclagem pra capacitação. Capacitação lembra capacidade, então as professoras professoravam sem capacidade? Quer dizer que não estavam ainda capacitadas? E como já davam aula? E depois, capacidade é sempre limitada, tem um máximo possível, só cabe aquele tanto. ${ }^{1}$ Se estão "enchendo" de novo, é porque já gastaram o que sabiam? Ou tiram o velho pra pôr o novo? Ou não tinham enchido até a borda antes? Ou esvazia enquanto dá aula? O trabalho esvazia a capacidade, em vez de produzi-la?

Mas, que estará acontecendo com Rosa e Miriam lá em seus cursos? Divago e quase perco tudo. Ei, e é a Miriam que está falando, acho que está perguntando alguma coisa.

- A Emília fez um método para alfabetizar, é um método novo, muito bom. Os resultados com ele são ótimos. A criança aprende mesmo. Quem não aprende com ele, olha, não sei não... É um método, uma maneira dela trabalhar que eu acho que tem muita coisa do antigo, uma maneira dela trabalhar que é diferente, mas também é igual... Tem algumas coisas de como se trabalhava antes, o que tem diferença é a questão da letra de mão e da letra de fôrma, ela trabalha mais só com letra de fôrma, mas eu acho que se ela tem que ir, então tem que ir com as duas... Muitas vezes a gente faz o tal teste pra saber em que estágio ela está e é a mesma coisa da tal prova, “é prova hoje...” Eu não estou gostando do resultado que estou vendo nas crianças, elas não estão escrevendo assim já na época do ano, pelo que a gente vê das outras classes, elas não estão lendo como deveriam estar, lendo até estão, mas escrevendo não... Ela lê e não escreve... É uma maneira de trabalhar diferente, mas na hora de avaliar praticamente é a mesma coisa. ${ }^{2}$

- Sim, isto é interessante, mas foge do nosso assunto de hoje, que são as etapas de desenvolvimento descritas por Piaget, se você quiser podemos discutir isto no fim da aula, se sobrar um tempinho.

- Mas, Dona Maura, eu queria juntar toda esta teoria com o que acontece na minha sala de aula... "Eu fico assustada. Você faz um trabalho diferente e tem que avaliar da forma antiga. Não é muito certo, não, é uma angústia que eu sinto, um negócio por dentro de mim, as crianças estão aí e não se percebe rendimento bom, a questão da avaliação, da promoção, eu não estou muito animada não...”

- Depois, Miriam, agora não dá, está atrapalhando os outros! Ei!, Pessoal! Atenção aqui!

Segundo Jullien (1996, p. 165), um dos aspectos marcantes da cultura grega, e por isso de nossa cultura, é conceber uma forma ideal, 
que se torna o objetivo das ações práticas: "A teoria é a construção dessa forma ideal que colocamos como objetivo; a prática é o esforço que procura aproximar o objeto do modelo".

Nossas construções teóricas decorrem de sistematizações de um conjunto de conhecimentos prévios, hipóteses, novas idéias e experiências anteriores. Essa sistematização é fundamental para o avanço do conhecimento e é ela que será a base de novas sistematizações, padronizações e normas que orientarão a aplicação da teoria. A isso temos chamado de método: os caminhos a serem percorridos para a produção de novos enunciados válidos no interior da disciplina.

O método, elaboração teórica resultante do embate das formulações idealizadas com o empírico, está presente em todas as áreas do conhecimento, de tal sorte que estamos sempre construindo nossas ações à imagem do modelo que nós mesmos propomos (ou elaboramos) e estamos sempre atentos às imperfeições das práticas, imperfeições que atribuímos a erro de percurso no método de suas realizações. Estamos sempre desejosos de uma padronização que resulte da sistematização de conhecimentos científicos, que permita aplicações, comparações, análises. Desejosos de certezas, não percebemos que novos conhecimentos são tecidos coletiva e historicamente, pelo constante embate entre o mundo das teorias e o mundo real.

Por isso, a norma não é mais do que um mapa indicativo de caminhos, que não existe desenraizado da teoria - formulações idealizadas e mutáveis. O método orienta e facilita a aplicação das teorias, porém não tem vida autônoma; o método, a norma, a técnica, ou que outro nome lhe for dado, enrijece-se sem a oxigenação que lhe dão teorias e práticas associadas. Um método independente, a-histórico, lugar de formulação de juízos entre o verdadeiro e o falso, é um desastre em potencial para o mundo real, onde vivem os seres humanos reais.

Para usar adequadamente uma padronização, reconhecer suas possibilidades e limites, compará-la a outras e decidir-se por ela em determinada situação concreta, é necessário conhecer muito bem as teorias subjacentes, às quais cada método se subordina.

Voltemos às salas de aulas das universidades, com suas práticas implicitamente permeadas por concepções de conhecimento como objeto pronto e acabado e que enxergam o aluno como uma capacidade a ser preenchida, para que enfim esteja ele também pronto para ser entregue ao mercado. Nesses espaços, em que a docência é refém da necessidade de exibir "produtos", em que predomina um ensino tecnificado e 
imediatista, há pouco tempo a perder com teorias, com conhecimentos, com saberes. Aprende-se a repetir: ação padronizada pelo método. Nas academias não há mais espaço para a sabedoria. Ensinam-se as técnicas, os métodos, as normas, tornados órfãos da teoria. Nas academias, teoria e prática são transformadas em objetos distintos, estanques, separáveis.

$\mathrm{O}$ estudante aprende e prende-se ao uso de um resultado de conhecimentos sem se perguntar por sua geração; nessa condição, o método de produção é ingerido nas entrelinhas do processo de ensino e aprendizagem. O que é múltiplo se reduz a um; mediocrizados, todos se igualam, anulando-se divergências e incompatibilidades teóricas.

Paradoxalmente, tratar o conhecimento como objeto de trocas faz privilegiar as técnicas, mas sem discutir o como.

Discutir o como não é mesmo fácil. Isso pela enorme distância entre fornecer/prender as regras de uma técnica e saber a lógica em que se fundam essas mesmas regras. Para aplicá-las com sabedoria, isto é, para descobrir nas situações suas propensões, flexibilizando, inovando e criando estratégias de acordo com as situações concretas, é necessário saber, ter constituído seu próprio conhecimento com a sensibilidade para perceber o que ocorre a cada momento. Saber implica disponibilidade para enxergar e respeitar o outro, com todas as suas diferenças. Tem de haver a sabedoria de saber fazer. Aí, teoria e prática não mais competem entre si, exibem-se inseparáveis.

O não-enfrentamento das dificuldades relativas ao como, desvelado pelas poucas situações em que é discutido, é um dos alicerces da fragmentação entre discurso e ação, entre teoria e prática. Tematizar $o$ como é também fornecer ao outro as chaves que não trouxe, critérios para a avaliação da própria prática que se está fazendo acontecer. Nossas fragilidades nas práticas afugentam nossa coragem para submergir no acontecimento. Desviamo-nos, escudados na velha fórmula, sempre atual: não dou receitas. Ainda que ninguém as tenha pedido, como Miriam não as pediu. Discutir os comos não é dar receitas, mas questionar evidências tão caras que delas próprias não nos apercebemos: é pôr sob suspeição conhecimentos, saberes, seus modos de produção e circulação.

Em oposição ao modelo, tal como aquele a que a tradição grega nos habituou, gostaria de apresentar aquilo que me parece ser próprio da tradição chinesa, que é o de detectar nas coisas uma propensão à obra. Neste caso, o ponto de partida não é o modelo que eu concebo mas a situação que se me oferece: descubro nela os fatores em que me posso apoiar para atingir o meu objetivo. (Jullien, 1996, p. 165) 
$\mathrm{Na}$ crista das ondas em que se afogam nossas certezas e ilusões, muitos daqueles a quem se outorgou o papel de prescrever, de dar receitas, frustram-se porque se percebem ditando regras para ninguém, eis que seu objeto não mais é regular as formas da ação dos sujeitos entre si e dos sujeitos com as coisas, mas perguntar, sem respostas definitivas, sobre as relações dos sujeitos com seus processos de constituição.

D aqui de cima, de longe, é mais fácil enxergar o que acontece lá embaixo, ter uma visão mais ampla, perceber os entornos. A gente perde em detalhes, mas ganha em totalidade. A proximidade pode atrapalhar, às vezes confunde, mescla emoções, paixões, realidade. Para enxergar o canavial, é preciso sair dele, sob o risco de só se ver alguns pés de cana. Outras vezes, a proximidade é essencial, pois o que se perde em amplitude, se ganha em detalhes. Quando se quer ver o pé de cana, é necessário entrar no canavial, mas cuidado para não chegar perto demais, pois aí se pode achar que uma folha é todo o pé de cana. A distância a ser mantida depende do que se quer ver. Se for a molécula da sacarose, bem, aí tem mesmo é que estar dentro da cana. Os fotógrafos sabem já há tanto tempo as diferenças entre a lente grande angular, a olho-de-peixe e o zoom, assim como as vantagens e a hora de melhor usar cada uma...

Olha lá, Rosa e Miriam estão saindo do curso. Nossa! Por que será que andam tão depressa, nem sei como se equilibram naquelas sandálias, ai meu tornozelo! Selecionar lentes, ajustar o foco, aproximaaaaar!!!

- Ai, Rosa, assim não dá, você está correndo muito rápido!

-É que preciso correr pra pegar o Pedrinho na creche, dar o almoço rapidinho, e depois levar na consulta com a pediatra. Não posso perder a hora, senão depois leva um tempão pra marcar de novo.

- E como ele está da anemia?

- Não sei, vou lá hoje pra ver os exames. Mas até já sei, vai ser de novo aquela mesma lenga-lenga, a senhora não está dando o remédio direito, precisa dar na hora certa, precisa comer carne, precisa isto, precisa aquilo, precisa, precisa! $\mathrm{Na}$ escola precisa, em casa precisa, aqui no curso precisa, com meu marido precisa. Não agüento mais, queria poder querer em vez de tanto precisar. Acho que você me entende...

-É, também me sinto assim, a "moça do precisa”. Mas, afinal, você está tratando direito a anemia do Pedrinho, dá o sulfato ferroso certinho?

- Ah! Mais ou menos, né, Miriam? Do jeito que a doutora Angélica quer que eu faça, é um horror! Não dá! Não faço outra coisa a não ser cuidar de filho, nem posso mais trabalhar.

- Mas, por quê?

- Ih! É cheio de regras e horários, tem que dar uma hora antes de comer, escovar os dentes depois, aí come e escova de novo, e tem dia que fica com o cocô mole, dá um trabalhão, aí eu paro mesmo, mesmo ela dizendo que não pode. $\mathrm{E}$ 
também dou um pouquinho menos, dou só 20 gotas, e não 30 . Assim parece que ele aceita melhor.

- Mas você perguntou pra médica se pode?

- Pra quê? Pra levar bronca? É lógico que ela vai dizer que não pode, que se pudesse ela já tinha feito isso. Aí vou lá e juro que estou fazendo tudo direitinho como ela mandou, as 30 gotas e tudo. E nem conto que de vez em quando esqueço.

- Mas, Rosa!!!

- Ah, Miriam, ele está melhorando e assim me dá menos trabalho. E depois, quem é que nunca esquece de nada? Gente que é gente esquece, só máquinas não falham, e olhe lá... Vai me dizer que a doutora Angélica nunca esqueceu de dar um remédio pro filho dela?

E lá vão elas correndo pra pegar o ônibus.

Barra! Pra ela e pra doutora. Uma ditando regras sem conhecer a vida da outra, com todas as suas dificuldades, e a outra desafiando as regras, parece que resistindo pra se manter dona de sua vida e de seu nariz. Dona de quê? Com tanto precisa isso, precisa aquilo, precisa...

Olha lá a doutora conversando depois de atender o Pedrinho e tantas outras crianças que ela conhece sem conhecer:

- Eu sinto que não consigo, por mais que tente não consegui ainda conversar de verdade com as mães, sinto que fico falando, falando, mas não consigo chegar lá, dizer de um jeito que elas entendam o porquê das coisas e não apenas acreditar em mim e me obedecer.

- Deixa de sonhar Angélica, você precisa falar firme e de-va-gar, pra que elas entendam e façam direito o que você mandou. Fazendo que convence, mande. - Não é nada disso, Ricardo. Não queria ter que convencer, que dirá mandar. Queria saber como fazer pra elas entenderem, pra saberem o que acontece, porque precisa ser dado o remédio desse jeito... Âs vezes, acontece, como hoje com a mãe da Paula, sinto que cheguei perto, que consegui. Mas não sei o que foi que fiz, por que foi que deu certo. E é isso que quero saber...

Difícil mesmo é aceitar que na vida se pode ter diferentes distâncias, ângulos, focos para ver a mesma coisa e que todos eles têm sua importância, basta saber sua hora e seu lugar e trabalhar com todos, para tentar aproximações mais adequadas do mundo real, onde pessoas reais, de carne e osso, vivem suas vidas reais. Cotejar, comparar, compatibilizar diferentes visões, esta é a base da arte de viver. No mundo da ciência ainda não, mas no mundo da vida, já faz tempo...

Muitas vezes, a melhor fotografia, a mais bonita, é aquela que foi tirada por acaso, aquela em que se pensou ter errado o foco. Aquela que, por acaso, contra todas as previsões, simplesmente aconteceu. Aí, precisa saber aproveitar o acaso, o que aconteceu sem estar previsto e aprender com ele.

Mas aqui no alto, é mais fácil pensar, refletir, analisar o que aconteceu. Difícil mesmo é mudar a vida, o dia-a-dia, a partir dos momentos privilegiados de 
livre pensar. Difícil é levar pro mundo da vida o mundo da ciência: sem definitivos. Difícil é levar pro mundo da ciência o mundo da vida: acontecimentos e acasos.

Agnes Heller, ao discutir aspectos da vida cotidiana e suas interrelações com a história da humanidade, afirma:

A vida cotidiana é a vida de todo homem. Todos a vivem, sem nenhuma exceção, qualquer que seja seu posto na divisão do trabalho intelectual e físico. (...) o homem participa na vida cotidiana com todos os aspectos de sua individualidade, de sua personalidade. Nela, colocam-se "em funcionamento" todos os seus sentidos, todas as suas capacidades intelectuais, suas habilidades manipulativas, seus sentimentos, paixões, idéias, ideologias. (Heller, 1989, p. 17)

Uma das características fundamentais da vida cotidiana - e das formas de pensamento que a regem - é a heterogeneidade: a vida colocanos demandas, extremamente distintas entre si e sempre todas exigindo respostas imediatas, de modo que sobre nenhuma delas é possível se deter inteiramente. Entretanto, existem momentos que poderíamos chamar de privilegiados - e aos quais apenas a minoria das pessoas tem acesso em nossa estrutura social - em que ocorre a suspensão do cotidiano. São momentos em que, pelo distanciamento das exigências e necessidades da vida, consegue-se a homogeneidade de pensamento para debruçar-se sobre uma questão específica e única (pelo menos naquele espaço de tempo); homogeneizar o pensamento significa concentrar toda a atenção, todas as energias em uma única questão, suspendendo, temporariamente, qualquer outra atividade. Estes momentos, em que se consegue um distanciamento das próprias particularidades, para priorizar a comunidade humana, o gênero humano, propiciam a integração ao humano-genérico, transformando nossa inteira individualidade bumana, o homem inteiro que intervém na cotidianidade, em inteiramente bomem.

Esta suspensão do cotidiano ocorre quando focalizamos, olhando não mais apenas a partir de nossas particularidades, questões que dizem respeito à coletividade. Agnes Heller destaca os campos da ética, da política, da arte e da ciência como espaços privilegiados para que se consiga a decolagem do cotidiano e elevação ao humano genérico. Entre elas, a arte e a ciência são as formas de elevação que podem produzir objetivações duradouras.

A arte realiza tal processo porque, graças à sua essência, é autoconsciência e memória da humanidade; a ciência da sociedade na medida em que 
desantropocentriza (ou seja, deixa de lado a teologia referida ao homem singular); e a ciência da natureza, graças a seu caráter desantropomorfizador. (Heller, 1989, p. 26)

Entretanto, todos, inclusive artistas e cientistas, vivem suas vidas cotidianas; nascemos já inseridos na cotidianidade.

Antes de mais nada, o próprio cientista ou artista têm vida cotidiana: até mesmo os problemas que enfrentam através de suas objetivações e suas obras lhes são colocados, entre outras coisas (tão-somente entre outros, decerto), pela vida. Artista e cientista têm sua particularidade individual como homens da cotidianidade; essa particularidade pode se manter em suspenso durante a produção artística ou científica, mas intervém na própria objetivação por meio de determinadas mediações (na arte e nas ciências sociais, por meio da mediação da individualidade). Finalmente, toda obra significativa volta à cotidianidade e seu efeito sobrevive na cotidianidade dos outros. (Heller, 1989, p. 27)

Se entendermos que "a vida cotidiana não está fora da história, mas no próprio centro do acontecer histórico, sendo a verdadeira essência da substância social" (op. cit.: 20), perceberemos a importância de romper as disjunções, as dicotomias, entre teorias e práticas, entre discursos e ações, enfim, entre pesquisar e tentar transformar a vida cotidiana de todos, homens, mulheres e crianças.

O desafio maior consiste em, ao retornar à vida cotidiana, modificála; é na cotidianidade que as teorias, as idéias, as propostas se concretizam ou não. Teorias, idéias, propostas que não conseguem - ou não se preocupam com - a transformação da vida cotidiana, vivem apenas no campo das idéias de alguns indivíduos, sem repercussões, sem existência para a imensa maioria das pessoas.

Ser capaz de se elevar à esfera do humano-genérico, suspendendo a vida cotidiana e suas infindáveis solicitações, e daí ser capaz de transformar seu próprio cotidiano é essencial se pretendemos ser sujeitos de nossa própria história. Se, porém, pretendemos ser agentes efetivos de transformação social, sujeitos da História, fica o desafio de sermos capazes de nos infiltrar na vida cotidiana, quebrar seu sistema de preconceitos e retomar a cotidianidade em outra direção. (Collares \& Moysés, 1996, p. 234)

A preocupação com os usos e as conseqüências dos conhecimentos, com o rompimento das barreiras ao acesso da maioria da humanidade às possibilidades de melhoria da vida concretamente postas pelo avanço inegável da ciência, constitui um dos elementos fundantes da insatisfação com a modernidade científica. 
Cada vez mais cientistas apontam a necessidade de se assumir a responsabilidade pelas idéias e teorias lançadas do mundo da ciência para o mundo da vida, buscando inclusive indícios que permitam antecipar suas conseqüências para a vida das pessoas. É urgente que os sentidos e caminhos que idéias, teorias e discursos assumem e percorrem depois de emitidos sejam tomados por objetos de pesquisa. Trata-se de buscar entender esse buraco negro onde caem os processos discursivos para, entendendo-o, nele intervir.

Um objeto de pesquisa ainda por ser definido, elaborado, requerendo um método específico, ainda inexistente. A esfinge avisava: decifra-me ou te devoro. Sua versão cabocla, oculta sob a aparência de bicho-papão, cuja existência aprendemos a negar, matreiramente nos devora, nos assimila, se fortalece com nossas idéias. É este o desafio: desvelar o bicho-papão (ou, se preferirem, a esfinge). Não enfrentar o desafio significa continuarmos sendo seu alimento. (Moysés \& Collares, 1997, p. 114)

Sem dúvida, alguns temas facilitam este tipo de reflexão, assim como alguns métodos de pesquisa. Assim, é de se esperar que pesquisadores que lidam com seres humanos sejam mais sensíveis a estas questões. Do mesmo modo, métodos que propiciem maior interação entre quem pesquisa e quem é pesquisado, como a pesquisa-ação, propiciam maiores possibilidades de perceber o outro como sujeito a não ser assujeitado.

Entretanto, deve-se ressaltar que, embora assunto e método possam ser facilitadores, não constituem garantia de uma postura crítica e reflexiva. Não são suficientes e não devem ser encarados como necessários, pois todo e cada cientista, não importa sua área de estudos, necessita vincular-se às preocupações com a coletividade e com o futuro. Aliás, nunca é demais lembrar que estas questões surgiram exatamente nos chamados campos de conhecimento duro. Talvez porque tenha sido exatamente neles que as cobranças da natureza tenham sido primeiro percebidas e onde o paradigma da ciência moderna tenha dado seus primeiros sinais de esgotamento.

A ciência moderna propôs-se a desvelar as leis universais e deterministas que regeriam o universo, em todas as suas dimensões, desde os movimentos de astros até as interações moleculares dentro de uma célula.

Nesse processo de desencantamento do mundo, sob a égide dos mitos da neutralidade e da objetividade, perderam-se alguns valores essenciais com que enxergar a vida, de tal sorte que, progressivamente, o mundo da ciência foi se separando do mundo da vida, como denunciou 
Morin: "A ciência clássica havia desintegrado o cosmos, havia desintegrado a vida dizendo que a vida não existia, que há moléculas, comportamentos, gens, mas, a vida? Que é isso? Não a conheço!” (Morin, 1996b, p. 276).

No final do século 20, dissemina-se a percepção de que pessoas e natureza não constituem recursos infindáveis porque auto-renováveis e que, sob pena de se inviabilizar um futuro não distante, é necessário alavancar reflexões sobre os usos e conseqüências das ciências, tecendo novos consensos éticos que privilegiem a vida. Afinal, "não se ditam normas à vida, cientificamente” (Canguilhem, 1982, p. 185).

Alterar as formas de produção, circulação e apropriação do conhecimento para salvar a vida, para preservar o futuro, buscar tecer novas relações entre as pessoas, delas com todos os seres vivos e de todos com a natureza. Este o desafio premente.

É evidente que um mundo onde domine a inovação é um mundo incerto, sem determinismo, sem fim, sem objetivos. Mas é também um mundo de liberdade e de responsabilidade.

Um mundo de liberdade, evidentemente, uma vez que o determinismo e a liberdade se opõem. É aí que reside talvez o paradoxo do Século das Luzes, que inventou simultaneamente os gérmens da liberdade (Voltaire, Diderot...) e do determinismo (Newton...). Por que razão o segundo se sobrepôs à primeira? Não foi simplesmente porque, desde a noite dos tempos, o homem procura explicações capazes de reduzir a sua angústia existencial fundamental: que existe detrás da vida e, evidentemente, para além dela?

Se constatamos não o fracasso do determinismo mas, pelo menos, os seus limites, não deveríamos devolver o primeiro lugar à filosofia? (Raux, 1996, p. 15)

Reencantar o mundo, redescobrir a vida

Quanto ao destino, que algumas pessoas encaram como o dono de todas as coisas, faz rir o sábio. Com efeito, vale mais aceitar ainda o mito dos deuses do que subjugarmo-nos ao destino dos físicos. Porque o mito deixa-nos a esperança de nos reconciliarmos com os deuses, através das honrarias que lhes prestamos, ao passo que o destino tem um inexorável cunho de necessidade. (Epicuro, citado por Prigogine, 1996a)

O quase abismo existente entre o mundo da ciência e seus processos discursivos e o mundo da vida e sua cotidianidade é responsável, pelo menos parcialmente, pela desconfiança com que as pessoas lidam com os discursos da ciência. Em sua pesquisa sobre as relações que membros 
das classes populares estabeleciam com seu próprio corpo e com os discursos médicos, Luc Boltanski fala de uma confiança que desconfia, pela percepção da relação de poder estabelecida pelo saber:

Sabe-se que "os outros" possuem conhecimentos, meios materiais e direitos que lhes conferem extensos poderes, e dão-lhes a possibilidade de manipulação ou então, necessariamente, a vontade de manipular. Mas como a relação de força é aqui demasiado desigual e para desmascarar tal manipulação ou evitá-la seria preciso possuir poderes equivalentes aos do manipulador, os membros das classes populares não têm outros recursos para se defender e se assegurar senão a desconfiança e a caçoada, o mau humor e a suspeita. (Boltanski, 1989, p. 40)

As formas de circulação dos conhecimentos que predominam na modernidade retroalimentam, em um círculo viciado, as relações entre poder e saber, analisadas por Foucault.

O indivíduo é sem dúvida o átomo fictício de uma representação "ideológica" da sociedade; mas é também uma realidade fabricada por essa tecnologia específica de poder que se chama a "disciplina". Temos que deixar de descrever sempre os efeitos de poder em termos negativos: ele "exclui", "reprime", "recalca", "censura”, "abstrai", "mascara", "esconde”. Na verdade o poder produz; ele produz realidade; produz campos de objetos e rituais da verdade. O indivíduo e o conhecimento que dele se pode ter se originam nessa produção. (Foucault, 1996b, p. 172)

Ao conceber o conhecimento como objeto externo e independente do sujeito, com vida quase autônoma, a ser transmitido, transformado em objeto de trocas, e o sujeito como mero observador e portador desse objeto-mercadoria, a ciência tem afastado o sujeito de seus saberes, negando-lhe o direito de se constituir pela tessitura de si próprio e de seus conhecimentos.

É precisamente a reflexão sobre os diferentes modos de relacionarse com saberes e conhecimentos, "apreendendo" o sujeito do cotidiano em seu convívio com os outros e com as realidades objetais, que está produzindo um novo quadro de referências para o discurso da ciência: salienta-se a importância do acaso e do acontecimento ${ }^{3}$ registra-se como essencial a noção de irreversibilidade do tempo; ${ }^{4}$ o reconhecimento de que o caos, a desordem e a crise constituem formas mais complexas do que a mera ausência de ordem originou a teoria/ciência do caos. ${ }^{5}$

Estas novas concepções que invadem o mundo das ciências trazem consigo o questionamento da universalidade da ciência, substituindo as leis deterministas por "consensos locais e parciais", exigindo uma nova 
ética nas relações dos seres humanos entre si e com a natureza, recordandonos a necessidade de respeitar a complexidade e a singularidade coexistentes em cada ser vivo e em cada acontecimento histórico.

Certamente as lutas de Giordano Bruno, para além de seu final trágico, inspiram preocupações contemporâneas. Se na segunda metade do século 16 Bruno defendia que a uma nova concepção de mundo deveria corresponder uma nova concepção de homem e de organização social, nesse final do século 20 , o redesenho dos fundamentos da ciência, lembrando finitudes e incertezas, reintroduziu a questão da subjetividade como lugar fundamental de realização e constituição de uma singularidade marcada pela complexidade.

A chamada "virada lingüística", dando centralidade à linguagem no processo de constituição da subjetividade, mostrou que são singulares, mas compartilhados, os modos de articulação entre o que se repete - o retorno de estruturas lingüísticas - e o que se organiza/estrutura como novo a cada processo de fala. $\mathrm{O}$ sujeito, ao enunciar, enuncia-se, desvelando as origens de sua constituição - o já-dito que retorna - e também marcando as particularidades de sua internalização desse já-dito por meio das palavras usadas na interpretação. $\mathrm{O}$ acontecimento de sua enunciação é um novo enunciado resultante das formas de articulação próprias do já-dito com seus dizeres anteriormente internalizados, que se tornam a nova vestimenta do que o sujeito enuncia aqui e agora.

Tomando as formas de funcionamento da linguagem como inspiração - uma relação dialética entre o já-dito e o que se diz - e considerando que a subjetividade se constitui como feixes de representações lingüísticas internalizadas, reconfigura-se a noção de sujeito: uma singularidade histórica, por isso única, cuja existência depende do outro, que lhe é externo, sendo ele próprio um exterior de constituição do outro. Trata-se de um movimento contínuo de constituição, como se fora um jogo de espelhos em que a imagem refletida diz o que espelha, mas somente diz em face da presença inicial que "impõe" ao espelho um dizer, ao mesmo tempo em que o espelho lhe "impõe" como retorno a própria imagem modificada pelo jogo entre espelhos. Na imagem está o "eu" que se olha, mas a imagem não é o "eu" que olha.

Este movimento interlocutivo, encontro do um com o outro, é sempre um acontecimento possível porque lugar de construção de "consensos locais e parciais" de inter(in)compreensão: a cada dizer do outro fazemos corresponder nossas próprias palavras para interpretá-lo. E essas palavras somente são próprias pelo esquecimento de suas origens (Bakhtin, 1992), pois provieram de outros momentos de interlocução, 
e já internalizadas nos pertencem porque pertencem também aos outros. Mas como cada um de nós tem uma história de interlocuções prévias, nada de antemão garante que a palavra que usamos para construir nossa interpretação corresponda à interpretação desejada pelo outro.

No mundo da vida, compreendemo-nos por meio de consensos lingüísticos locais e parciais. Hoje, o mundo da ciência reconhece que não há universalidades, determinações e precisões. Também aí há consensos locais e parciais.

Para Morin, a existência do sujeito está ligada a dois princípios de incerteza:

(...) quando falo, ao mesmo tempo que eu, falamos "nós"; nós, a comunidade cálida da qual somos parte. Mas não há somente o "nós”; no "eu falo" também está o "se fala". Fala-se, algo anônimo, algo que é a coletividade fria. Em cada "eu" humano há algo do "nós" e do "se". Pois o eu não é puro e não está só, nem é único. Se não existisse o se, o eu não poderia falar.

(...)

Há um segundo princípio de incerteza, o de que o sujeito oscila, por natureza, entre o tudo e o nada. Para si mesmo, ele é tudo. Em virtude do princípio egocêntrico está no centro do mundo, é o centro do mundo. Mas, objetivamente, não é nada no universo, é minúsculo, efêmero. Por um lado há uma antinomia entre esse privilégio inaudito que o "eu" concede a si mesmo e a consciência que podemos ter de que essa coisa, a mais sagrada e a mais fundamental, nosso tesouro mais precioso, não é nada de nada. Estamos divididos entre o egoísmo e o altruísmo. (...) A morte, para cada sujeito, é o equivalente à morte do universo. É a morte total de um universo. E, por sua vez, essa morte revela fragilidade, o quase nada dessa entidade que é o sujeito. Mas, ao mesmo tempo, somos capazes de buscar essa morte, horror, quando oferecermos nossas vidas pela pátria, pela humanidade, por Deus, pela verdade. (Morin, 1996c, p. 54-55)

Partindo das reflexões sobre a linguagem, chegamos a uma noção de sujeito inacabado, em constante processo de constituição, nos e pelos acontecimentos irreversíveis de sua história singular. Uma tal noção de sujeito exige uma correspondente indeterminação nas formas de compreender o mundo. Partindo das críticas à ciência moderna, possíveis pela aplicação de alguns de seus princípios, especialmente a segunda lei da termodinâmica, chegamos a uma noção de ciência que desloca certezas e reintroduz a "seta do tempo". Uma tal concepção de ciência exige uma correspondente alteração na forma de compreender a subjetividade.

Estas concepções de ciência e de sujeito alertam que os caminhos das relações entre sujeitos e conhecimentos não se dão pelos processos 
de transmissão, em que conhecimentos são tornados objetos e sujeitos são tomados como recipientes, mas se constroem na caminhada, na aventura de constituir-se nos/pelos processos de internalização, através da experiência, entendida esta como aquilo que nos acontece e não simplesmente como aquilo que acontece (Larrosa, 1999).

Tal como outros Giordanos, vivemos uma época de novas configurações em construção. Estamos no meio do redemoinho, e no meio do redemoinho está o diabo, ensina Guimarães Rosa.

Pelos céus da cidade, vôo leve e livre: apenas aprendendo a conhecer. Ah! sim, outro compromisso: aprendendo a respeitar as diferenças, sem perdoar as desigualdades. Vá lá, aprendendo tudo que se puder, que os acasos e acontecimentos derem a chance.

Devo confessar algo que talvez possa ser considerado amarra: que vontade desesperada de comer ambrosia!!! A Emília, do Sítio do Pica-Pau Amarelo, tinha razão: ambrosia é mesmo o néctar dos deuses, o alimento do Olimpo. Até nem consigo pensar direito de tanta vontade, não é fome não, é von-ta-de!

Também não é fácil, toda vez que flagro aqueles três, lá estão eles comendo cada doce! E lá estão, de novo... Esperem, só vejo a Cecília e a Cida, cadê o Wanderley, sumiu? Ah! Lá vem ele, chegando com uma cocada em cada mão. Duas cocadas pra três? Parece divisão de salário mínimo. Ou será que tem gente de dieta? Nada disso, lá vem ele de novo, com mais duas cocadas. As dele! Huumm... sequinhas por fora, derramando calda à primeira mordida. De babar...

E eles falam que falam, não entendo como se entendem falando um ao mesmo tempo que o outro. Atropelam-se:

- Mas eu acho que o nó é exatamente este. Por que é que afinal o porqueiro do Agamenon não se convence? ${ }^{6}$ Porque ele tem que engolir o que um outro fala, engolir e pronto. Ele é só o recipiente do conhecimento, e olhe lá!

- Tá certo, eu entendo sua angústia, eu também sinto isso cada vez que falo uma coisa e escuto dizerem que eu falei um negócio totalmente diferente. Ainda outro dia, estava dando aula sobre produção de textos por crianças e sobre a noção de erro em linguagem e de repente uma aluna virou pra mim e falou: "Mas isso é o que você acha! Eu acho que é erro mesmo!” E quando tentei explicar que não era uma questão de achismo mas de conhecimento, de um saber acumulado e que isso não podia ser deletado só porque não se concorda, sem argumentos, foi um bafafá. E ainda disseram que eu estava sendo autoritário...

- Isso me lembra quando fui entrevistar uma professora, na nossa pesquisa, e ela disse, sem localizar muito bem quem era eu: "Dizem por aí que desnutrição não tem nada a ver com fracasso escolar. Mas tem sim! Eu sei!"” Aí, fiquei com cara de tacho, não sabia se ria ou chorava. Depois de anos e anos dando cursos para professores no Brasil inteiro, do Oiapoque ao Chuí, sinto que adiantou muito pouco. Quando acreditam, é porque acreditam em mim e na Cida, não porque conseguiram saber. 
- Vira questão de fé. E aí a gente fica igual àqueles que a gente critica...

- Então, mas isso faz um tempão que vira e mexe estamos discutindo. A questão é: como? Que o jeito que eu converso com uma mãe na consulta não adianta, eu já sei. Que não pode querer transmitir, também sei, ela é quem precisa constituir seu próprio saber. Tão vendo como já aprendi! Mas o que aprendi não me responde: que que eu faço pra que uma mãe constitua seu saber sobre a anemia, por exemplo? Ou sobre a diarréia? Como??

- É isso aí, como dar aula sem transmitir? Como operacionalizar o que estamos sempre propondo, o que já tem tanta gente discutindo, escrevendo? Como é que me relaciono com o outro respeitando sua condição de sujeito???

- Tá na hora de arregaçar mangas e enfrentar o famoso como. Porque, em teoria, tem um monte de gente pensando como nós. Só que não se chega lá, não se fala de como se faz pra ser assim. A gente já ameaçou chegar perto no texto do buraco negro. ${ }^{8}$ Naquele texto, a gente falava do compromisso que precisamos ter com os caminhos e sentidos que nossas palavras tomam depois de lançadas ao ar. Isto é, no papel, né?

- Olha, já andei ciscando nestes assuntos. Claro, pensando o ensino de língua materna. Primeiro aprendi com todo mundo a fugir do assunto, com o clichê do professor universitário: não tenho que dar receitas. Mais tarde, fui percebendo que as perguntas dos professores eram verdadeiras perguntas.

- Peraí, mas é que...

- Mas aí, ao assumir que eram perguntas verdadeiras, me perdi, fiquei emaranhado em inúmeros problemas, desde a explicitação clara de concepções de ciência e sociedade até sua articulação coerente com as atividades possíveis ante os acontecimentos de sala de aula. É difícil ser coerente ao assumir que dos acontecimentos somente podemos extrair princípios, nunca ferramentas com que operar, pois um acontecimento leva a outro acontecimento que leva a outro e assim vai...

- É o cotidiano de vida aparentemente repetitivo, mas de fato é sempre na repetição que se pode perceber o deslocamento quase invisível que é preciso enxergar para viver.

- Subiram no banquinho, e fizeram discurso, hein?

- Por que será que na vida as crianças aprendem e quando se formaliza a aprendizagem, na escola, aparece a dificuldade? Com adulto é a mesma coisa...

- Talvez, se a gente lembrasse de como aprendeu, achasse algumas chaves...

- É mesmo, a gente quando adulto apaga da memória a criança que fomos. E fica falando de crianças que não existem de carne e osso. Até parece que sempre fomos adultos...

- Taí! A memória pode ser uma das chaves. E memória é passado, é tempo, coisa que não existe na teoria. Talvez lembrando e falando das lembranças...

- Narrando. A narrativa pode ser outra chave?

- Acho que é por aí! 
- Parece que pra crescer a gente precisa matar a criança em nós. Matamos e nunca mais falamos dela, nem de sua morte.

- Mas a gente só cresce conversando, só aprende nas interlocuções, nas narrativas. A vida é isto: passado, tempo, memórias, conversas, histórias, lembranças e com isto vamos aprendendo e aí

- O interessante é que para ensinar temos que nos deslocar para o futuro, e do lugar do futuro olhar nossas lembranças do passado para delas extrair o que ensinar no presente...

- É o tempo... cronologicamente irreversível, mas retomado nas narrativas. $\mathrm{Na}$ vida aprendemos com os “causos". A gente cresce ouvindo, depois envelhece contando... Veja só: talvez o tempo da enunciação, do contar, do falar, seja o único tempo reversível.

- Menos na sala de aula.

- Nem na ciência.

- Deve ser por isso que fica tão mais árido. Fica sem vida...

- Sem ar... Sem água...

- Sabe que vocês falando tudo isso, me lembrei de um causo meu, acho que tem tudo a ver. Uns anos atrás, estava fazendo uma pesquisa sobre dores recorrentes em crianças, dor de cabeça, dor nas pernas e na barriga. Na metade do século, tinha uns trabalhos interessantes, mostrando que a somatização é uma causa importante dessas dores.

- E criança também somatiza?

- Lógico, quando é que você acha que a gente aprende a descarregar no próprio corpo as dores dos sapos que engolimos? E nem precisa ser sapo grande, não. Sério, as crianças reagem aos limites, aos nãos que escutam da vida.

- Mas... e o caso que você tava contando...

- Então, antigamente as dores nas pernas eram chamadas de dor de crescimento. E elas acontecem nas idades em que a criança cresce menos.

- E agora? Como chama?

- Agora chama de vários nomes, todos mais bonitos, reumatismo de partes moles, fibromialgia, e por aí. E daí, quando eu dava aula disso, até brincava dizendo que tudo o que se sabia sobre as dores de crescimento era que não tinham nada a ver com crescimento. Até o dia em que eu estava conversando numa consulta com uma criança, de uns sete anos, que tinha dor nas pernas e de repente ela me falou: "Mas crescer dói!" Aí caíram todas as minhas fichas de uma vez só! Me lembrei de mim criança, lembrei que eu tinha dor na perna e minha mãe fazia banho com infusão de folha de eucalipto, lembrei de mim com medo do que eu não sabia. E aprendi que ignorante era eu, e não os médicos antigos...

- Eles sabiam que é difícil crescer, que dói... E era disso que falavam, né?

- É. Mas uma criança precisou me fazer lembrar de mim mesma, me contar de sua vida pra eu lembrar da minha e aí poder saber. E olhe que eu sempre fui 
fascinada pelo Peter Pan, quer dizer, eu estava o tempo todo ligada a coisas que me diziam que crescer dói, só que não conseguia ouvir. Talvez por estar ligada demais.

- E aí vêm a literatura, as artes, pra nos permitir o distanciamento necessário. É impressionante como a literatura já falou há muito tempo de coisas que só se está discutindo mais recentemente.

- E tem mais, crescer dói porque é irreversível, olha aí o tempo da vida de novo. Se a gente pudesse crescer, experimentar, voltar a ser criança, crescer de novo, ir e vir livremente no tempo, crescer poderia arranhar um pouquinho, mas não seria esta dor tão intensa...

- E olha aí a vida de novo se confrontando com as afirmações dogmáticas da ciência. É no mundo da vida que o tempo nos enfrenta, quase nos bate na cara sua irreversibilidade; enquanto isso, no mundo da ciência, continuamos a brincar de um faz-de-conta, dizendo que o tempo e todas as coisas são reversíveis.

- Tudo isto, esta história da criança que sacou que crescer dói, até me arrepia... Dá até vontade de ousar dizer que talvez o como repouse na interlocução. $\mathrm{Na}$ memória. Na vida. Aí, talvez a gente resgate o sujeito e seus processos de constituição de si próprio e de seus saberes... Será que é por aí???

- Isso me lembra aquela frase linda do Morin sobre a verdade, como é que é mesmo? Aquela que diz que de nada vale encontrar a verdade se ela não tiver sido tecida por nós, constituída por nós e em nós...

- "Nada é mais pobre que uma verdade sem sentimento da verdade."

\section{Recebido em maio de 2001. \\ Aprovado em agosto de 2001.}

\section{Notas}

1. Quando se fala em inteligência, o termo capacidade é usado predominantemente por aqueles que partilham da concepção inatista, que pretende que a inteligência é um dom inato ao indivíduo, geneticamente determinado e independente das condições concretas de vida; além disto, essa concepção pretende que a inteligência de cada um é quantitativamente definida, com um máximo possível - o potencial intelectual. "Burt, um dos psicólogos eugenistas de maior repercussão, por seus estudos sobre inteligência em gêmeos criados separados, escreveu em 1947: Se a inteligência é inata, o grau de inteligência de uma criança é permanentemente limitado. (...) A capacidade deve obviamente limitar o conteúdo. É impossivel um jarro de meio litro conter mais do que meio litro de leite; e é igualmente impossível que os resultados educacionais de uma criança sejam maiores do que permite sua capacidade educável. (Burt, apud Lewontin et al., 1984, p. 87; tradução pessoal). Após sua morte, em 1971, Burt foi desmascarado como autor de uma das maiores fraudes em ciência, sendo provado que todos seus relatos sobre gêmeos foram inventados.” (Moysés, 1998, p. 145)

2. As falas deste turno e do próximo turno, aqui atribuídas à personagem Miriam, são de uma professora de primeira série do primeiro grau, entrevistada em pesquisa realizada nas escolas públicas municipais de Campinas (Collares \& Moysés, 1996, p. 207-208). 
3. “A história é 'instável'. Todos conhecem o conto do cavalo que tinha um cravo frouxo, que, ao soltar-se, o fez perder uma ferradura, e a perda da ferradura impediu ao ginete seguir cavalgando, e a demora do ginete conduziu à queda de um império. $\mathrm{O}$ acontecimento mais insignificante pode mudar o curso da história. Em contraste com isso, supunha-se que a natureza era estável e que a ciência podia alcançar a certeza." (Prigogine, 1996b, p. 26)

4. Para grande número de epistemólogos, uma das mais notáveis conseqüências do estabelecimento de leis deterministas que regeriam a natureza foi a eliminação da "seta do tempo"; o tempo retorna como questão a partir da segunda lei da termodinâmica vinculada com a entropia. Prigogine (1996b) retoma o assunto, explicitando os momentos fundamentais do "paradoxo do tempo" para a ciência moderna.

5. "O mundo, tal como o vê a caótica, é rico em evoluções imprevisíveis, cheio de formas complexas e fluxos turbulentos, caracterizado por relações não-lineares entre causas e efeito, e fraturado entre escalas múltiplas de diferente magnitude que tornam precária a globalização. (...) A ordem pode ser conceitualizada não como uma condição totalizadora mas como uma duplicação de simetrias que permitem assimetrias e imprevisibilidades." (Schnitman, 1996, p. 13)

6. Em seu livro Pedagogia profana, Jorge Larrosa utiliza como epígrafe do texto "Agamenon e seu porqueiro" o apólogo de Juan de Mairena: "A verdade é a verdade, diga-a Agamenon ou seu porqueiro. - Agamenon: De acordo. - O porqueiro: Não me convence.” (Larrosa, 1999, p. 149).

7. Esta fala é de uma professora de primeira série do primeiro grau, entrevistada em pesquisa realizada nas escolas públicas municipais de Campinas (Collares \& Moysés, 1996).

8. "O buraco negro entre o conhecimento científico e o mundo real: um objeto essencial de pesquisa.” (Moysés \& Collares, 1997)

9. Edgar Morin, Amor, poesia, sabedoria, 1999, p. 33.

\section{Referências Bibliográficas}

BAKHTIN, Mikhail. (1920-1930) Estética da criaşão verbal. São Paulo: Martins Fontes, 1992.

BOLTANSKY, Luc. As classes sociais e o corpo. $3^{\circ}$ ed. Rio de Janeiro: Graal, 1989.

BORGES, Jorge Luís. Obras completas, vol. II (O fazedor). São Paulo: Globo, 1999.

CANGUILHEM, George. O normal e o patológico. $2^{\circ}$ ed. brasileira. Rio de Janeiro: Forense-Universitária, 1982.

CARO, Paul. A roda das ciências: Do cientista à sociedade, os itinerários do conhecimento. Lisboa: Instituto Piaget, 1995.

COLLARES, Cecília A.L.; MOYSÉS, Maria Aparecida A. Preconceitos no cotidiano escolar: Ensino e medicalização. São Paulo: Cortez-FE/ FCM Unicamp, 1996. 
FOUCAULT, Michel. A ordem do discurso. São Paulo: Edições Loyola, 1996 a.

. Vigiar e punir: Nascimento da prisão. 14ํㅡ. ed. brasileira. Petrópolis: Vozes, 1996b (1º ed. em 1977).

HELlER, Agnes. O cotidiano e a História. 3o ed. Rio de Janeiro: Paz e Terra, 1989.

JULLIEN, François. "A arte do desvio". In: Morin, Edgar et al., $A$ sociedade em busca de valores: Para fugir à alternativa entre o cepticismo e o dogmatismo. Lisboa: Instituto Piaget, 1996.

LARROSA, Jorge. Pedagogia profana. Belo Horizonte: Autêntica, 1999.

MORIN, Edgar. "Epistemologia da complexidade". In: Schnitman, Dora Fried (Org.), Novos paradigmas, cultura e subjetividade. Porto Alegre: Artes Médicas, 1996a.

. "Complexidade e liberdade". In: Morin, Edgar et al., $A$ sociedade em busca de valores: Para fugir à alternativa entre o cepticismo e o dogmatismo. Lisboa: Instituto Piaget, 1996.

. "A noção de sujeito". In: Schnitman, Dora Fried (Org.), Novos paradigmas, cultura e subjetividade. Porto Alegre: Artes Médicas, 1996 a.

. Amor, poesia, sabedoria. Lisboa: Instituto Piaget, 1999.

MOYSÉS, Maria Aparecida A. A institucionalização invisível: Crianças que não-aprendem-na-escola. Tese de livre-docência em Pediatria Social, Faculdade de Ciências Médicas, Unicamp. Campinas, 1998.

.; COLLARES, Cecília A. L. "O buraco negro entre o conhecimento científico e o mundo real: Um objeto essencial de pesquisa". In: Reali, A. M.; Mizukami, M. G., Formação do educador: Tendências atuais. São Carlos: Editora da UFSCar, 1997.

PRIGOGINE, Ilya. "O reencantamento do mundo". In: MoRin, Edgar et al., $A$ sociedade em busca de valores: Para fugir à alternativa entre o cepticismo e o dogmatismo. Lisboa: Instituto Piaget, 1996.

. "O fim da ciência?”. In: Schnitman, Dora Fried (Org.), Novos paradigmas, cultura e subjetividade. Porto Alegre: Artes Médicas, 1996a. 
RAUX, Jean-François. "Elogio da Filosofia para construir um modo melhor". In: Morin, Edgar et al., $A$ sociedade em busca de valores: Para fugir à alternativa entre o cepticismo e o dogmatismo. Lisboa: Instituto Piaget, 1996.

SANTOS, Boaventura Souza. Um discurso sobre a ciência. Lisboa: Afrontamento, 1987.

SARAMAGO, José. Ensaio sobre a cegueira. São Paulo: Companhia das Letras, 1995.

SCHNITMAN, Dora Fried "Introdução: Ciência, cultura e subjetividade". In: Schnitman, Dora Fried (Org.), Novos paradigmas, cultura e subjetividade. Porto Alegre: Artes Médicas, 1996a. 